\title{
ASSOCIATION BETWEEN GALL BLADDER DIAMETER AND CALCULUS IN THE CYSTIC DUCT IN GALL STONE DISEASES AND ITS IMPORTANCE IN THE CURRENT SURGICAL PRACTICE- A CROSS- SECTIONAL STUDY IN JNIMS, POROMPAT, MANIPUR
}

\author{
O. Heramot Singh ${ }^{1}$, N. Somorjit Singh ${ }^{2}$, Ruma Sarkar ${ }^{3}$, Th. Hemchandra Singh ${ }^{4}$
}

${ }_{1}^{1}$ Associate Professor, Department of Radiodiagnosis, Jawaharlal Nehru Institute of Medical Sciences, Porompat, Manipur. ${ }_{2}^{2}$ Associate Professor, Department of Surgery, Jawaharlal Nehru Institute of Medical Sciences, Porompat, Manipur. ${ }^{3}$ Assistant Professor, Department of Radiodiagnosis, Jawaharlal Nehru Institute of Medical Sciences, Porompat, Manipur. ${ }^{4}$ Assistant Professor, Department of Surgery, Jawaharlal Nehru Institute of Medical Sciences, Porompat, Manipur.

ABSTRACT
BACKGROUND
Gall Stone Disease is still a problem even in this new era. Patients with suspected gall bladder disease visiting Jawaharlal Nehru
Institute of Medical Sciences, Porompat, Manipur (JNIMS) were diagnosed by doing ultrasound examination in the Department of
Radiodiagnosis, JNIMS. Sometimes, it is difficult to trace the complete cystic duct and was overlooked, especially in obese patients
which in fact needs further evaluation by Computerised Tomography (CT)/ Magnetic Resonance Imaging (MRI).
The objective of this study is to assess the association of gall bladder diameter and calculus in the cystic duct.

\section{MATERIALS AND METHODS}

All patients with suspected Gall Bladder Disease visiting Jawaharlal Nehru Institute of Medical Sciences, Porompat, Manipur (JNIMS) from 1st Feb 2016 to 15th March 2017 between the age group of 18 - 70 yrs. irrespective of sex and race were examined in Department of Radiodiagnosis, JNIMS. All are examined by Transabdominal Ultrasonography (USG) and selectively with CT/ MRI for confirmation. The confirmed Gall Stone Diseases (GSD) were taken up for Cholecystectomy in JNIMS and operative findings were correlated with the USG and CT/ MRI findings and were analysed.

Study Design- A cross-sectional study.

Setting- Jawaharlal Nehru Institute of Medical Sciences, Porompat, Manipur (JNIMS).

\section{RESULTS}

Out of 586 patients, a total of 500 cases, aged 18 - 70 yrs. were studied. 65 cases were found calculus in the Gall Bladder (GB), Cystic duct, Common Bile Duct (CBD) or combined. Total number of cases having only GB calculi was 38. GB calculi and cystic duct was 16 cases. Total number of cystic duct calculus only was 7 (USG-3, CT-2 and MRI-2). GB with cystic duct and CBD calculi was 3 and CBD only was 1 . All the intraoperative findings are similar with the pre-operative USG, CT/ MRI reports. Patients with Gall Bladder diameter $>3.5 \mathrm{~cm}$ are associated with stone in the cystic duct.

\section{CONCLUSION}

Symptomatic patients showing a gall bladder diameter of $>3.5 \mathrm{~cm}$ or more should be further evaluated for the cystic duct calculus, so as it will help complete treatment in the GSD patients.

\section{KEYWORDS}

JNIMS, GB, GSD, CBD, USG, CT, MRI.

HOW TO CITE THIS ARTICLE: Singh OH, Singh NS, Sarkar R, et al. Association between gall bladder diameter and calculus in the cystic duct in gall stone diseases and its importance in the current surgical practice- a cross-sectional study in JNIMS, Porompat, Manipur. J. Evolution Med. Dent. Sci. 2018;7(07):856-859, DOI: 10.14260/jemds/2018/195
BACKGROUND
Cholelithiasis is one of the most common diseases diagnosed by USG and the confirmed cases needs surgical intervention sooner or later. The most common problem is post cholecystectomy cystic duct calculus, which may be detected in post-operative patient having recurrence of symptoms of pain in the upper abdomen. This is most unfortunate for both the patient as well as the treating surgeon and
'Financial or Other Competing Interest': None.
Submission 24-01-2018, Peer Review 05-02-2018,
Acceptance 07-02-2018, Published 12-02-2018.
Corresponding Author:
Dr. N. Somorjit Singh,
Associate Professor,
the ultrasonologist . However, the ultimate solution is further management, maybe to re-look at surgery.
The term cystic duct calculus refers to the stone in the duct connecting the gall bladder and common hepatic duct. Most of the ultrasound screening is confined to the gall bladder and CBD. Tracing of the cystic duct is difficult, sometimes not possible. Approximately, $80 \%$ of the patients with distended Gall Bladder $>3.5 \mathrm{~cm}$ may have calculus in the cystic duct. Further investigation is essential to find out calculus in the cystic duct, though preliminary ultrasound examination cannot detect the same. So, the study plans to assess the association between GB diameter and presence of Calculus in the Cystic duct.

Department of Surgery,

Jawaharlal Nehru Institute of Medical Sciences,

Porompat, Manipur.

E-mail: drnssingh@yahoo.com

DOI: 10.14260/jemds/2018/195

\section{MATERIALS AND METHODS}

\section{Study Design}

Cross-section study. 


\section{Study Population}

All symptomatic patients complaining of colicky and burning upper abdomen pain with or without vomiting attending JNIMS between the age group of 18 - 70 years, irrespective of sex and race during the study period.

\section{Setting}

Diagnostic procedures in the Radiology Department and operative procedure in the Surgery Department, JNIMS with intraoperative findings were used.

\section{Duration}

Study is for a period of 1 year $\left(1^{\text {st }}\right.$ Feb $2016-15^{\text {th }}$ March 2017).

\section{Sample Size}

All symptomatic patients suspected of gall bladder disease including the patients in Surgery Dept. Unit 1, who were having complaints of colicky and burning upper abdomen pain with or without vomiting attended in JNIMS during the study period.

\section{Sampling}

Consecutive sampling till the required size is obtained.

The Study starts from 1st Feb 2016 to $15^{\text {th }}$ March 2017. Study population consists of patients between the age group of 1870 yrs. irrespective of sex, race who are complaining of colicky and burning upper abdomen pain with or without vomiting. All patients underwent transabdominal ultrasound examination in JNIMS and in some patients, further evaluation with CT/ MRI was done.

\section{Inclusion Criteria}

All patients with symptoms of Gall Bladder disease and willing to participate in this study attended to at JNIMS including Surgery Unit 1 Dept. JNIMS, Porompat.

\section{Exclusion Criteria}

1. History of chronic cholecystitis.

2. Intrahepatic GB.

3. Congenitally small GB.

4. Previous history of operation in the biliary tree.

5. Post-traumatic patients.

\section{Procedure}

Patients were fully prepared by fasting, but in well-hydrated condition. Then ultrasound examination with the facility to Doppler examination with USG probe of 3.5 and 7.5 MHZ were used. Gall bladder, Cystic duct and CBD were scanned in different positions viz. supine, left lateral, rt. lateral and probed up position at 45 degrees to the bed in inspiratory and expiratory phases. Stomach was filled with water partially $(1 / 3$, i.e. about $300 \mathrm{~mL})$. Most of the time, Cystic duct was seen between the CBD and gall bladder.

All symptomatic patients complaining of symptoms of GSD i.e. colicky, burning upper abdomen pain with or without vomiting were scanned with Toshiba-Xerio, HD7 Philips colour Doppler machines. Patient having gall stone, cystic duct calculus and CBD calculus were segregated in the excel sheet for analysis. Most of the time, cystic duct calculus $>3$ $\mathrm{mm}$ causes distension of Gall Bladder $>3.5 \mathrm{~cm}$ in diameter and length $>7.5 \mathrm{~cm}$.

Some of the symptomatic patients with distended GB ( $>3$ $\mathrm{cm}$ in diameter) highly suspicious of cystic duct calculus were cross checked by USG before operative procedure and again in such patients having no stone in GB lumen but GB is dilated with colicky pain symptoms were scanned by CT/ MRI and found stone in the cystic duct.

All the stone confirmed patients were advised to followup with the surgeon. Intraoperative findings were discussed with the surgeon concerned for confirmation of the imaging reports. The intraoperative finding showed to have distended GB with stone impacted in the neck or cystic duct.

\section{Statistical Analysis}

Data was analysed using IBM SPSS Version 20 software. Descriptive statistics like mean, median, SD, analytical statistics, chi-square test, t-test etc. $\mathrm{P}$ value $<0.05$ is taken as significant.

\section{RESULTS}

A total of 586 symptomatic patients attended during the study period. Out of which, 86 patients did not fulfil the inclusion criteria. So, 500 patients were included in the study. Age (Yrs.): mean $\pm \mathrm{SD}=42.87 \pm 14.6$, Median age $=42$ yrs., range 18 to 70 years.

\begin{tabular}{|c|c|c|}
\hline Variable & Category & Frequency (\%) \\
\hline \multirow{3}{*}{ Symptom } & $\begin{array}{l}\text { Burning Pain Upper } \\
\text { Abdomen }\end{array}$ & 429 (85.8) \\
\hline & $\begin{array}{c}\text { Colicky, Burning } \\
\text { Upper Abdomen Pain }\end{array}$ & $48(9.6)$ \\
\hline & $\begin{array}{l}\text { Upper Abdomen Pain } \\
\text { with Vomiting }\end{array}$ & $23(4.6)$ \\
\hline \multirow{2}{*}{$\begin{array}{l}\text { GB and Cystic Duct } \\
\text { Calculi }\end{array}$} & Absent & 484 (96.8) \\
\hline & Present & $16(3.2)$ \\
\hline \multirow{2}{*}{$\begin{array}{l}\text { Cystic Duct, CBD } \\
\text { and GB Cal }\end{array}$} & Absent & 497 (99.4) \\
\hline & Present & $03(0.6)$ \\
\hline \multirow{2}{*}{$\begin{array}{c}\text { Cystic Cal only, } \\
\text { detected by (USG) }\end{array}$} & Absent & $497(99.4)$ \\
\hline & Present & $03(0.6)$ \\
\hline \multirow{2}{*}{$\begin{array}{l}\text { Cystic Duct Cal only } \\
\text { detected-CT (CT) }\end{array}$} & Absent & $498(99.6)$ \\
\hline & Present & $02(0.4)$ \\
\hline \multirow{2}{*}{$\begin{array}{l}\text { Cystic Duct Cal only } \\
\text { detected by (MRI) }\end{array}$} & Absent & 498 (99.6) \\
\hline & Present & $02(0.4)$ \\
\hline \multirow{2}{*}{$\begin{array}{l}\text { Total No. of Cases } \\
\text { having Cystic Duct } \\
\text { Calculus }\end{array}$} & Absent & 474 (94.8) \\
\hline & Present & $26(5.2)$ \\
\hline \multirow{2}{*}{ GB Diameter } & Up to $3.5 \mathrm{~cm}$ & $453(90.6)$ \\
\hline & $>3.5 \mathrm{~cm}$ & $47(9.4)$ \\
\hline 0 & $\begin{array}{l}\text { g Relationship of Lo } \\
\text { li with Frequency }\end{array}$ & ion of \\
\hline
\end{tabular}

\begin{tabular}{|c|c|c|c|}
\hline Variable & Mean (SD) & Median & Min-Max \\
\hline GB diameter $(\mathrm{cm})$ & $2.45(0.757)$ & 2.0 & $1-6$ \\
\hline GB length $(\mathrm{cm})$ & $6.46(1.218)$ & 6.0 & $3-11$ \\
\hline
\end{tabular}

\begin{tabular}{|c|c|c|c|}
\hline $\begin{array}{c}\text { Variable } \\
\text { Cystic Duct } \\
\text { Calculi }\end{array}$ & Gpto 3.5 cm N (\%) & $>\mathbf{3 . 5} \mathbf{~ c m ~ N ~ ( \% ) ~}$ & \\
\cline { 2 - 3 } Absent & $448(94.5)$ & $26(5.5)$ & \multirow{2}{*}{0.001} \\
\hline Present & $5(19.2)$ & $21(80.8)$ & \\
\hline Table 2. Comparison of Presence of Cystic Duct Calculi with \\
GB Diameter \\
\hline \multicolumn{3}{|c|}{} \\
\hline \multicolumn{3}{|c|}{}
\end{tabular}


Presence of cystic duct calculi is significantly higher in those patients whose GB diameter was more than $3.5 \mathrm{~cm}$ as compared to those whose diameter is lesser than $3.5 \mathrm{~cm}$ and the difference was found to be statistically significant $(\mathrm{p}<$ 0.001).

\begin{tabular}{|c|c|c|c|}
\hline Variable & \multicolumn{2}{|c|}{ Cystic Duct Calculi } & P-value \\
\cline { 2 - 3 } Type of Complaint & Absent N (\%) & Present N (\%) & \\
\hline $\begin{array}{c}\text { Burning Pain } \\
\text { Upper Abdomen }\end{array}$ & $415(96.7)$ & $14(3.3)$ & \\
\hline $\begin{array}{c}\text { Colicky, Burning } \\
\text { Upper Abdomen } \\
\text { Pain }\end{array}$ & $44(91.7)$ & $4(8.3)$ & \multirow{2}{*}{0.001} \\
\hline $\begin{array}{c}\text { Upper Abdomen } \\
\text { Pain with Vomiting }\end{array}$ & $15(65.2)$ & $8(34.8)$ & \\
\hline \multicolumn{2}{|c|}{$\begin{array}{c}\text { Table 3. Comparison of Type of Complaint } \\
\text { with Presence of Cystic Duct Calculi }\end{array}$} \\
\hline
\end{tabular}

Patients with complaints of upper abdominal pain with vomiting had a significantly higher risk of having cystic duct calculi as compared to patients with other symptoms $(\mathrm{p}<0.001)$.

\begin{tabular}{|c|c|c|c|c|}
\hline Variable & $\begin{array}{c}\text { GB Diameter } \\
(\mathrm{cm}) \text { Mean } \pm S D\end{array}$ & \begin{tabular}{|c|} 
Mean \\
Difference \\
$(95 \% \mathrm{CI})$ \\
\end{tabular} & $\begin{array}{c}\text { t- } \\
\text { value }\end{array}$ & $\begin{array}{c}\text { p- } \\
\text { value }\end{array}$ \\
\hline $\begin{array}{c}\text { Cystic duct } \\
\text { calculi absent }\end{array}$ & $2.37(0$ & \multirow{2}{*}{$\begin{array}{c}-1.551 \\
-1.818 \text { to }- \\
1.284)\end{array}$} & \multirow{2}{*}{-11.419} & \multirow{2}{*}{0.001} \\
\hline $\begin{array}{c}\text { Cystic duct } \\
\text { calculi present }\end{array}$ & $3.92(0.84)$ & & & \\
\hline
\end{tabular}

Table 4. Comparison of GB Diameter with Presence or Absence of Cystic Duct Calculi

The mean GB diameter of patients with cystic duct calculi was found to be significantly higher than the mean GB diameter of patients not having cystic duct calculi $(p<0.001)$.

\begin{tabular}{|c|c|c|c|c|}
\hline Variable & $\begin{array}{c}\text { GB Length } \\
\text { (cm) Mean } \pm \text { SD }\end{array}$ & $\begin{array}{c}\text { Mean } \\
\text { Difference } \\
\text { (95\% CI) }\end{array}$ & $\begin{array}{c}\text { t- } \\
\text { value }\end{array}$ & $\begin{array}{c}\text { p- } \\
\text { value }\end{array}$ \\
\hline $\begin{array}{c}\text { Cystic Duct } \\
\text { Calculi Absent }\end{array}$ & $\begin{array}{c}6.38 \\
(1.154)\end{array}$ & $\begin{array}{c}-1.622 \\
(-2.083 \text { to }\end{array}$ & -6.916 & 0.001 \\
\hline $\begin{array}{c}\text { Cystic Duct } \\
\text { Calculi Present }\end{array}$ & $\begin{array}{c}8.0 \\
(1.356)\end{array}$ & $-1.161)$ & & \\
\hline \multicolumn{3}{|c|}{ Table 5. Comparison of GB Length with Presence or } \\
Absence of Cystic Duct Calculi \\
\hline
\end{tabular}

The mean GB length of patients with cystic calculi was found to be significantly higher than the mean GB length of patients not having cystic duct calculi $(\mathrm{p}<0.001)$.

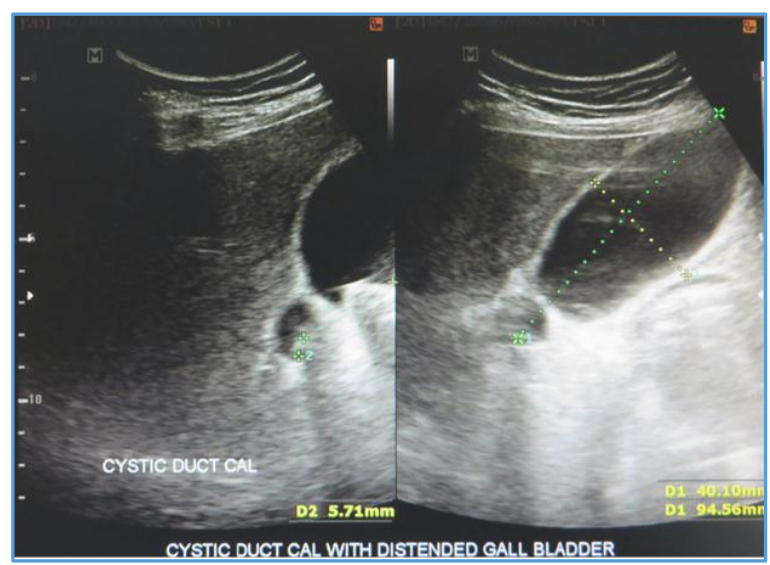

Figure 1. USG Picture of Distended GB with Cystic Duct Calculus

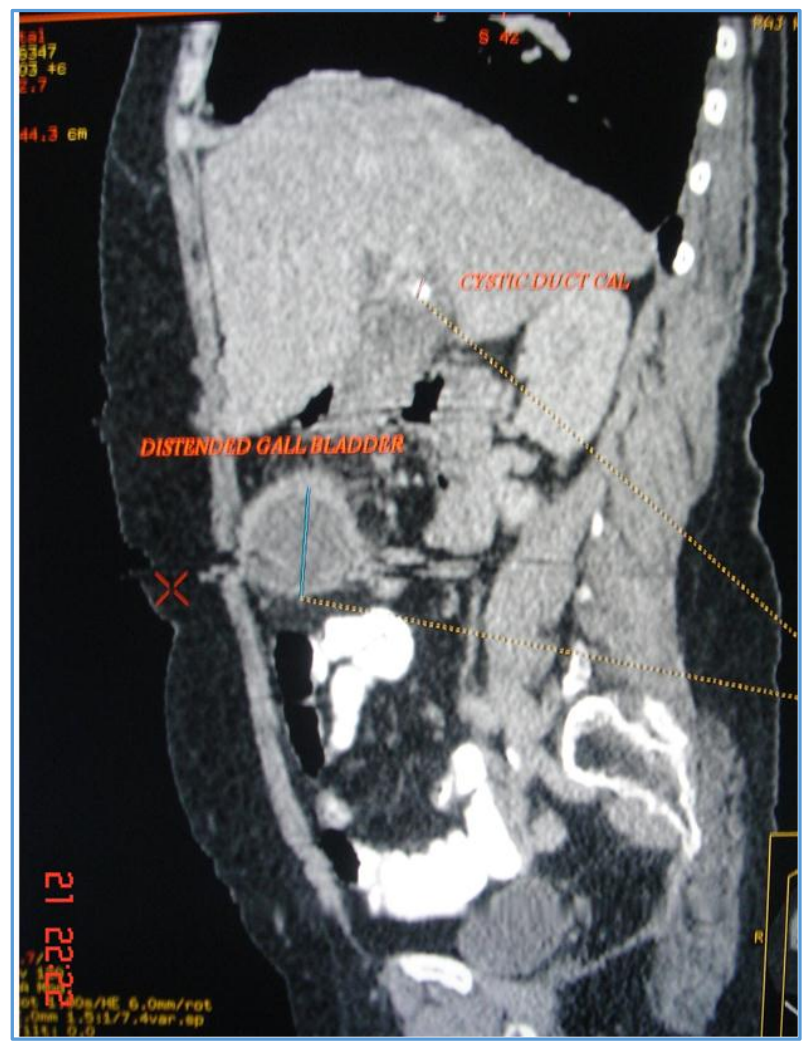

Figure 2. CT Picture of Distended GB with Cystic Duct Calculus

\section{DISCUSSION}

Gallstone disease is a common problem both in developing and developed countries, even in United States where > 700,000 cholecystectomies are done and costs $\sim \$ 6.5$ billion annually.(1) Diagnostic Ultrasonography is used as an important tool for determining the prevalence of gallstones.(2)

In Calculus Disease of Gall Bladder, $95 \%$ of cases of acute cholecystitis are caused by a stone obstructing the cystic duct. Small stones $(<3 \mathrm{~mm})$ may pass readily through the cystic duct. However, when calculus obstruction occurs, inflammation and distension of the gallbladder results. (3)

With the limitation of USG in the diagnosis of GB and hepatobiliary diseases, meticulous scanning is very important as many possible post-operative complications may be detected beforehand or treated in one go. Post-operative cystic duct calculus is one which presents after cholecystectomy and which may be overlooked during routine USG scan. $(4,5)$

In RM Walsh, JL Ponsky and J Dumot study, post cholecystectomy with signs and symptoms of biliary colic with jaundice and even pancreatitis were found due to the cystic duct remnant stone.(6)

Palanivelu C, Rangarajan M, Jategaonkar PA, et al observed that in Acute Cholecystitis with Cholelithiasis, sometimes a long cystic duct stump was left behind instead of dissecting too close to the common bile duct and right hepatic artery which again can be a predisposing factor for stone formation.(7)

In Sezeur A and Akel K study, Cystic duct stone is found frequently during cholecystectomy, so the surgeon's team needs proper preoperative evaluation of the cystic duct and also careful ligation of the cystic duct at its junction from common hepatic duct. (8) 
Benninger J, Rabenstein $\mathrm{T}$ and Farnbacher $\mathrm{M}$ et al showed successfully managed post-operative cystic duct remnant stone by extracorporeal shockwave lithotripsy along with the endoscopic removal of the stone fragments.(9)

In the study by Michael R Phillips, Mark Joseph and Evan $S$ Dellon et al, remnant cystic duct calculus after cholecystectomy may require surgical intervention.(10)

Mahmud S, Hamza Y and Nassar AH observed that some Cystic duct stones may slip from the gallbladder into the Cystic duct or the CBD during dissection. So the surgeon should do careful during retraction and manipulation during Cholecystectomy.(11)

In our study, out of 500 symptomatic patients, total number of calculus detected in the GB, cystic duct, CBD or combined were 65 cases. Total number of cases were only GB calculi 38, GB and Cystic duct calculi 16, Cystic duct calculus only 7 (USG-3, CT-2 and MRI-2) and GB with cystic duct and CBD calculi 3 and CBD only 1.

In our study, all the Symptomatic patients with distended GB, where cystic duct cannot be evaluated clearly, USG crosscheck was done and CT and MRI were performed accordingly.

During the study, some patients having diameter $>3.5 \mathrm{~cm}$ without any calculus in the biliary system is 5 cases. But 7 patients who had GB diameter of $>3.5 \mathrm{~cm}$ and length $>7.5 \mathrm{~cm}$ had cystic duct stone of $>3 \mathrm{~mm}$ in size causing distension of the GB (USG-3, CT-2 and MRI-2) with significance ( $<00.001)$.

\section{CONCLUSION}

USG diagnosis is the common tool for diagnosis of the GB and Hepatobiliary diseases. But meticulous screening USG, CT and MRI in the Symptomatic Gall Bladder disease patients will reduce confusion on imaging studies and also will reduce complications, subsequent surgical, endoscopic and percutaneous procedures.

\section{REFERENCES}

[1] Shaffer EA. Gallstone disease: epidemiology of gallbladder stone disease. Best Pract Res Clin Gastroenterol 2006;20(6):981-96.

[2] Kratzer W, Mason RA, Kächele V. Prevalence of gallstones in sonographic surveys worldwide. J Clin Ultrasound 1999;27(1):1-7.

[3] Turner MA, Fulcher AS. The cystic duct: normal anatomy and disease processes. Radiographics 2001;21(1):3-22.

[4] Htoo MM. Surgical implications of stone impaction in the gall-bladder neck with compression of the common hepatic duct (Mirizzi syndrome). Clin Radiol 1983;34(6):651-5

[5] Laing FC, Jeffrey RB. Choledocholithiasis and cystic duct obstruction: difficult ultrasonographic diagnosis. Radiology 1983;146(2):475-9.

[6] Walsh RM, Ponsky JL, Dumot J. Retained gallbladder/cystic duct remnant calculi as a cause of post-cholecystectomy pain. Surg Endosc 2002;16(6):981-4.

[7] Palanivelu C, Rangarajan M, Jategaonkar PA, et al. Laparoscopic management of remnant cystic duct calculi: a retrospective study. Ann R Coll Surg Engl 2009;91(1):25-9.

[8] Sezeur A, Akel K. Cystic duct remnant calculi after cholecystectomy. J Visc Surg 2011;148(4):e287-90.

[9] Benninger J, Rabenstein $T$, Farnbacher $M$, et al. Extracorporeal shockwave lithotripsy of gallstones in cystic duct remnants and Mirizzi syndrome. Gastrointest Endosc 2004;60(3):454-9.

[10] Phillips MR, Joseph M, Dellon ES, et al. Surgical and endoscopic management of remnant cystic duct lithiasis after cholecystectomy--a case series. J Gastrointest Surg 2014;18(7):1278-83.

[11] Mahmud S, Hamza Y, Nassar AH. The significance of cystic duct stones encountered during laparoscopic cholecystectomy. Surg Endosc 2001;15(5):460-2. 